Jurnal Akuntansi dan Bisnis: Jurnal Program studi Akuntansi, 5 (1) Mei 2019.

ISSN 2443-3071 (Print) ISSN 2503-0337 (Online). DOI: 10.31289/iab.v5i1.2042

JURNAL AKUNTANSI DAN BISNIS

Jurnal Program Studi Akuntansi

Available online http://ojs.uma.ac.id/index.php/jurnalakundanbisnis

\title{
PERANCANGAN SISTEM INFORMASI AKUNTANSI METODE SINGLE STEP UNTUK MENGHITUNG LABA RUGI STUDI KASUS PADA CHAMPION GYM CIREBON
}

\author{
Suwandi $a^{*}$, Marsani Asfi $a$, Viona Firlisia ${ }^{a}$, Sylvia Chandra ${ }^{a}$ \\ ${ }^{a}$ Sekolah Tinggi Manajemen Informatika dan Komputer CIC Cirebon \\ Diterima November 2018; Disetujui Februari 2019; Dipublikasikan Mei 2019
}

\begin{abstract}
Abstrak
Studi ini membahas permasalahan yang terjadi pada Champion Gym yang berhubungan dengan pencatatan akuntansi melalui perhitungan laporan laba rugi masih menggunakan cara manual yang belum menggunakan sistem komputerisasi yang sesuai dengan standar akuntansi. Dari hal tersebut keadaan ini menyulitkan manajemen dalam hal perhitungan laporan laba rugi setiap bulannya. Tujuan Penelitian ini adalah untuk membuat Aplikasi Sistem Perhitungan Laporan Laba Rugi Menggunakan Metode Single Step, yang diharapkan dapat membantu manajemen Champion Gym dalam melakukan perhitungan laba/rugi perusahaan setiap periode. Aplikasi perhitungan laba rugi menggunakan Metode Single Step ini dapat mempermudah manajemen Champion Gym dalam menghitung pendapatan, biaya serta laba/rugi yang dihasilkan setiap periode. Sehingga manajemen Champion Gym dapat mengetahui secara real mengenai laba / rugi perusahaan setiap periode akuntansi. Hasil dari sistem ini diharapkan menimbulkan dampak efisiensi dan efektivitas dalam operasional Gym serta mendapatkan laporan laba rugi yang akurat melalui hasil laba yang maksimal
\end{abstract}

Kata Kunci: Sistem Informasi Akuntansi, Pendapatan, Beban, Laba Rugi, Gym.

\begin{abstract}
This study discuss the problems in Champion Gym that are related to accounting records is the calculation of the income statement still using manual methods, not using a computerized system that complies with accounting standards. So that makes it difficult for management in terms of calculating the income statement every month. The purpose of this study was to create a Profit and Loss Report Calculation System Application Using Single Step Method, which is expected to help Champion Gym management in calculating the company's profit / loss for each period .. The profit and loss calculation application using the Single Step Method can facilitate the management of Champion Gym in calculate income, costs and profit / loss generated each period. So that Champion Gym management can find out in real terms about the company's profit / loss every accounting period. The results of this system are expected to have an impact on the efficiency and effectiveness of Gym operations and obtain an accurate income statement through maximum profit.
\end{abstract}

Keyword: Accounting Information Systems, Income, Expenses, Profit and Loss.

How To Cite: Suwandi, et, al. (2019). Perancangan sistem informasi akuntansi metode single step untuk menghitung laba rugi studi kasus pada champion Gym Cirebon. Jurnal Akuntansi dan Bisnis: Jurnal Program Studi Akuntansi, 5 (1): $22-33$

* email: suwandi@cic.ac.id 
Suwandi, et, al. (2019). Perancangan sistem informasi akuntansi metode single step untuk menghitung laba rugi studi kasus pada.....

\section{PENDAHULUAN}

Saat ini, kemajuan teknologi informasi berkembang dengan begitu pesat dari jaman ke jaman. Perkembangan teknologi yang sangat terasa dan berdampak pada kehidupan seharihari salah satunya adalah perkembangan teknologi berbasis komputer. Aplikasi berbasis komputer saat ini dapat membantu menyelesaikan pekerjaan di dunia indusri manapun, dalam mengolah data secara cepat, tepat dan akurat. Oleh karena itu, pemanfaatan teknologi dengan alat bantu komputer dapat menjadi salah satu solusi untuk mempermudah proses dalam menghasilkan suatu informasi (Fitri, et, al. 2018).

Laporan Laba Rugi perusahaan merupakan bagian dari laporan keuangan yang memuat informasi mengenai hasil operasi perusahaan, baik itu pendapatan maupun pengeluaran selama periode tertentu. Terdapat 2 (dua) bentuk laporan laba rugi, yaitu bentuk Single Step (langsung) dan bentuk multiple step (tidak langsung). Metode Single Step (langsung) adalah seluruh pendapatan yang ada dikelompokkan tersendiri di bagian atas dan dijumlahkan, lalu seluruh beban dikelompokkan tersendiri pula di bagian bawah dan dijumlahkan. Kemudian, jumlah pendapatan dikurangi jumlah beban, lalu selisihnya didapati laba bersih atau rugi bersih (Setianingsih, H. D. 2018).

Laporan pendapatan yang diterima dan biaya-biaya yang dikeluarkan oleh Champion Gym, pada saat ini belum dapat dihitung secara baik, sehingga belum dapat membuat laporan laba rugi sesuai dengan standar akuntansi, oleh sebab itu diperlukan sebuah sistem yang "mumpuni" dalam pelaporan keuangan akuntansi.

Tujuan penelitian ini adalah untuk memberikan solusi kepada manajemen Champion Gym dalam hal pembuatan aplikasi perhitungan laba rugi perusahaan, apakah memang akan memberikan dampak efisiensi dan pengingkatan laba dalam pelaksanaan sistematika informasi akuntansi dalam penghitungan single step.

Berdasarkan penelitian sebelumnya yang dilakukan oleh Purnomo (2015) dengan judul "Perancangan Aplikasi Pelaporan Keuangan Dana Bantuan Langsung Masyarakat Pengembangan Usaha Agribisnis Pedesaan Berbasis Web Studi Kasus, Lembaga Keuangan Mikro Agribisnis, Gabungan Kelompok Tani Rejo Makmur Desa Sitirejo. Menghasilkan aplikasi perangkat lunak untuk mempermudah proses pelaporan keuangan, laporan keuangan berbasis data uang masuk dan data uang keluar yang terdata di jurnal kas, laporan keuangan menghasilkan neraca, neraca saldo dan laporan rugi laba. Selanjutnya penelitian yang dilakukan oleh Setiawan (2016) dengan judul "Sistem Informasi Akuntansi Untuk UKM". Menghasilkan laporan laba rugi pada aplikasi akuntansi ini di luar pajak penghasilan, dan untuk laporan laba rugi pada tahun yang berjalan menggunakan jumlah persediaan barang yang terakhir saat laporan dibuat, bukan jumlah persediaan barang pada akhir tahun berjalan. Akumulasi penyusutan dihitung per hari sehingga dapat dilihat saldo akhir harta pada hari saat informasi dilihat.

\section{METODE PERANCANGAN PENELITIAN}

Jenis penelitian yang dilakukan adalah penelitian deskriptif. Penelitian deskriptif adalah penelitian yang mendeskripsikan dan menginterpretasikan sesuatu, misalnya kondisi atau hubungan yang ada, pendapat yang berkembang, proses yang sedang berlangsung, akibat atau efek yang terjadi, atau tentang kecenderungan yang sedang berlangsung.

\section{Tahapan Pengumpulan Data}

Berikut ini beberapa tahapan penelitian yang digunakan dalam pengumpulan data : 
Penelitian lapangan: berupa observasi dan wawancara, pertama melalui observasi adalah cara menghimpun bahan-bahan keterangan yang dilakukan dengan mengadakan pengamatan dan pencatatan secara sistematis terhadap fenomena-fenomena yang dijadikan obyek pengamatan. Dalam hal ini penulis mengamati seluruh aktifitas yang terjadi pada Champion Gym. Yang kedua adalah teknik wawancara, Wawancara yang dilakukan dengan cara memberikan pertanyaan kepada pemilik ataupun karyawan Champion Gym yang berkaitan dengan judul penelitian. Selanjutnya selain dari penelitian lapangan terdapat studi pustaka yang dalam proses pengambilan data dan informasi dengan cara mengumpulkan data, membaca literatur dan buku-buku, serta melakukan pencarian data-data yang diperlukan dalam pembuatan proyek kami melalui internet.

\section{Tahapan penerapan penelitian}

Pada tahapan penelitian kami mengadopsi metode dalam pengembangan perangkat lunak menggunakan Classic Life Cycle Model. Model ini merupakan model konvensional yang sering disebut sebagai Waterfall Model karena tahapan-tahapannya yang sistematis dan berurutan dalam membangun perangkat lunak.

\section{System Engineering (Rekayasa Sistem)}

Pada tahap ini pengerjaan dimulai dengan menentukan kebutuhan untuk seluruh elemen-elemen sistem dan mengalokasikannya untuk perangkat lunak.

\section{Analysis (Analisa)}

Pada tahap ini akan dilakukan kegiatan penelitian, memeriksa, mempelajari dan membandingkan data yang telah dikumpulkan dari proses sebelumnya. Selain itu tahapan ini dapat digunakan untuk mengidentifikasi masalah yang ada.

\section{Design (Desain)}

Pada tahap ini perancangan suatu sistem digambarkan dengan menguraikan alur sistem sampai alur dokumen yang akan dikembangkan dengan menggunakan tools antara lain: Flowchart, Flowmap, Diagram Konteks, DFD (Data Flow Diagram), ERD (Entity Relationship Diagram) dan Database.

\section{Coding (Pengkodean)}

Setelah melakukan perancangan desain, kemudian kami merubah desain tersebut menjadi bentuk yang dimengerti komputer yaitu dengan memberikan coding atau pengkodean pada perangkat lunak tersebut.

\section{Testing (Uji Coba)}

Setelah tahapan pengkodean selesai dan program dapat digunakan, testing atau uji coba dapat dilaksanakan. Testing difokuskan pada logika internal dari perangkat lunak, fungsi ekternal dan mencari segala kemungkinan kesalahan.

\section{Maintenance (Perawatan)}

Program yang telah dibuat dan berjalan dengan baik harus dilakukan proses perawatan agar sistem yang dirancang tetap dapat digunakan dengan baik. 
Suwandi, et, al. (2019). Perancangan sistem informasi akuntansi metode single step untuk menghitung laba rugi studi kasus pada.....

\section{HASIL DAN PEMBAHASAN}

\section{Analisa Sistem Berjalan}

Analisa sistem berjalan dilakukan untuk mengetahui sistem yang sedang berjalan pada Champion Gym Cirebon. Bagian-bagian dari analisa sistem berjalan mencakup sejarah dari perusahaan, struktur organisasi diperusahaan, tugas dan fungsi bagian di perusahaan, dokumen yang digunakan perusahaan, bagian yang terkait, prosedur naratif dan flowchart dokumen sistem akuntansi perusahaan.

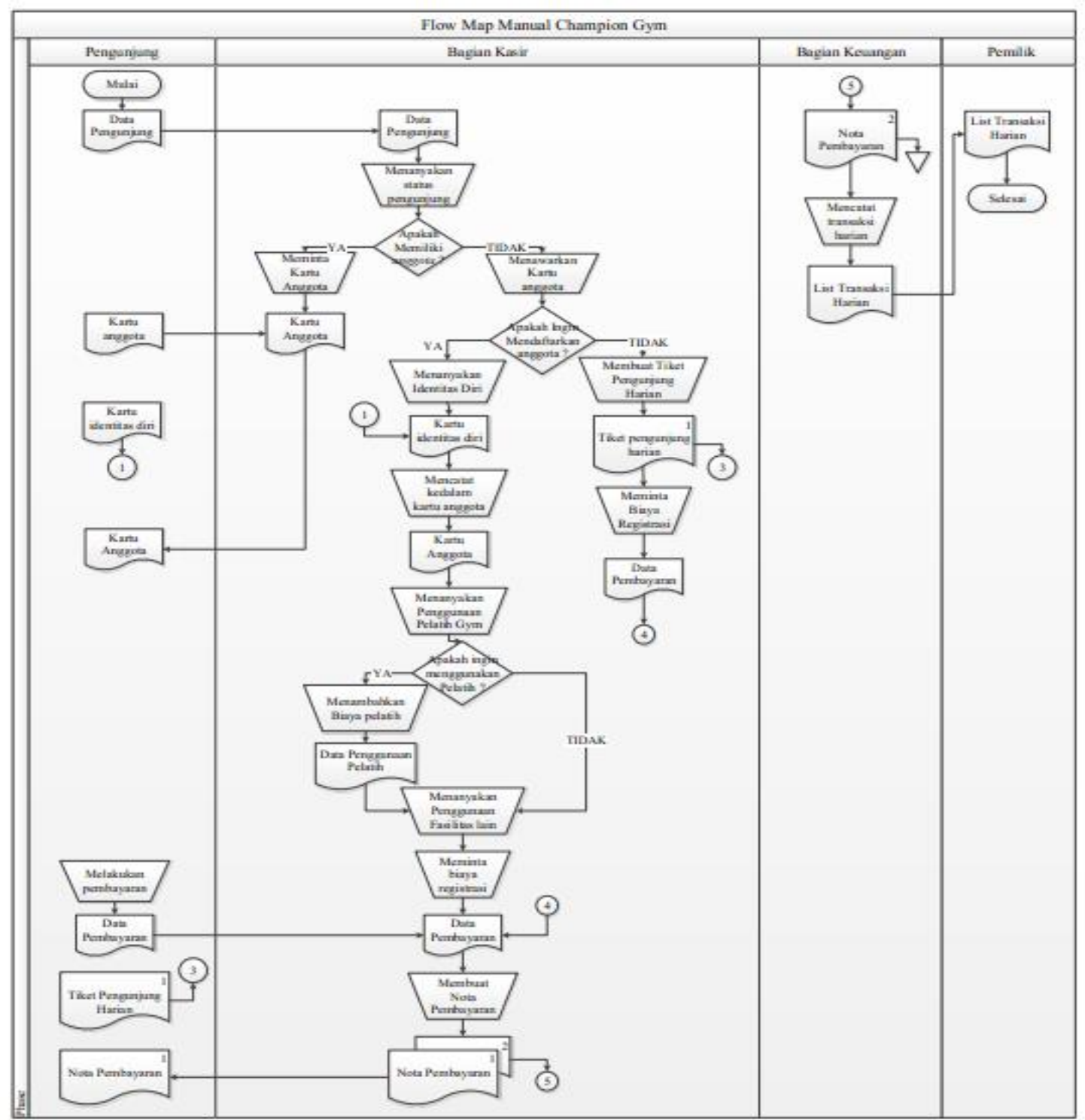

Gambar 1.1. Flowmap Manual Champion Gym 
Dari analisa sistem berjalan maka flowmap usulan aplikasi Perhitungan Sistem Laporan Laba Rugi Menggunakan Metode Single Step dapat dilihat dalam gambar 1.2 dibawah ini:

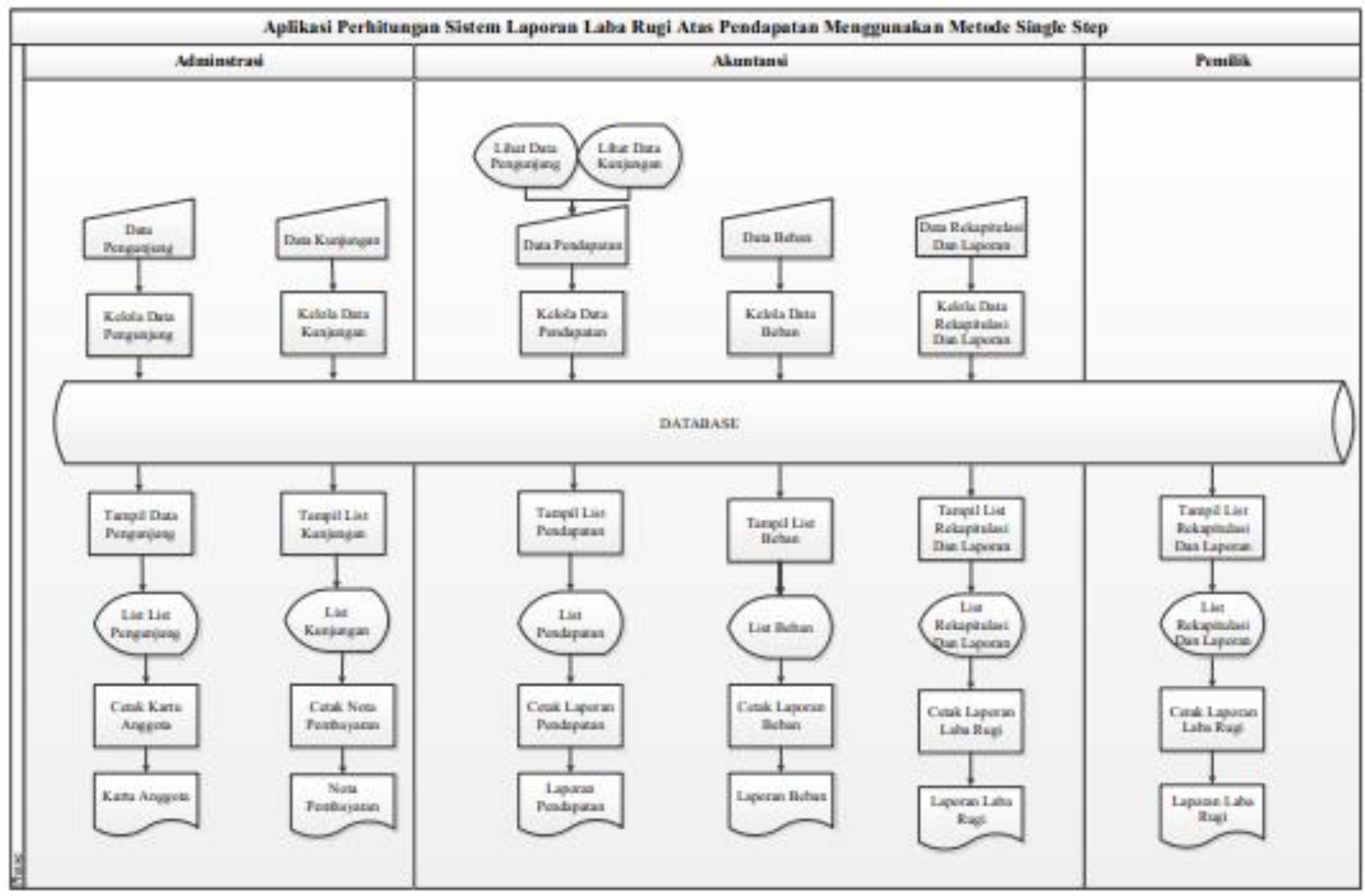

Gambar 1.2 Flowmap Prosedur Perhitungan Sistem Laporan Laba Rugi Menggunakan Metode Single Step

Keterangan :

List Pengunjung terdiri dari pengunjung harian dan pengunjung anggota member.

List Kunjungan terdiri dari transaksi yang terjadi yang berasal dari pengunjung harian dan pengunjung anggota member, penggunaan pelatih dan penggunaan fasilitas lain lain yang berupa makanan dan minuman yang ada di Champion Gym.

List Pendapatan terdiri dari segala transaksi yang berupa pendapatan penggunjung harian, pengunjung anggota member, penggunaan pelatih dan pembelian fasilitas lain lain seperti makanan dan minuman yang ada di Champion Gym.

List Beban terdiri dari biaya yang di keluarkan yaitu biaya gaji, biaya listrik, beban telepon, beban air, beban fasilitas, beban pelatih, beban penyusutan peralatan, bebanpemeliharaan aktiva tetap dan beban penyusutan gedung.

List Rekapitulasi dan Laporan terdiri dari seluruh rekapitulasi laporan pendapatan, laporan beban dan laporan laba rugi yang dapat dilihat dalam periode tertentu.

\section{Diagram Konteks ( Context Diagram )}

Didalam sebuah sistem akuntansi, diagram konteks merupakan gambaran prosedur secara global yang menjelaskan tentang aliran input, proses, dan output data - data yang diperlukan, seperti pada gambar 1.3 sebagai berikut : 
Suwandi, et, al. (2019). Perancangan sistem informasi akuntansi metode single step untuk menghitung laba rugi studi kasus pada.....

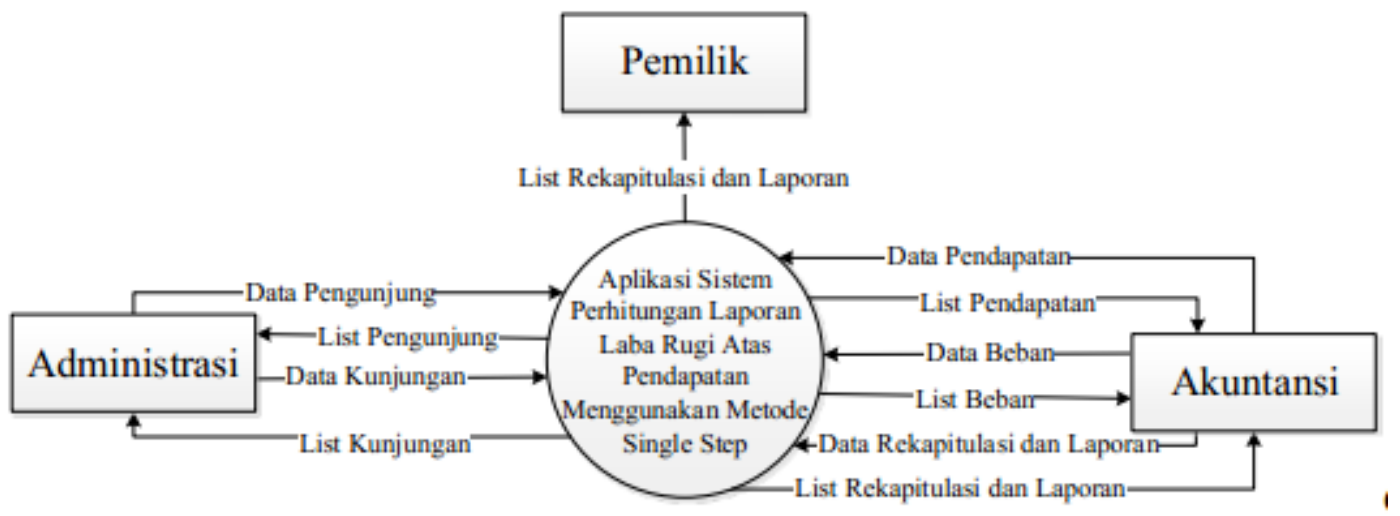

Gambar 1.3 Diagram Konteks Aplikasi Sistem Perhitungan Laporan Laba Menggunakan Metode Single Step

Diagram Aliran Data ( Data Flow Diagram / DFD ) Level - 0

Dalam sebuah prosedur DFD Level-0 merupakan tahapan yang menggambarkan proses data yang di Champion Gym diuraikan dari proses utama yaitu dari diagram konteks menjadi bagian- bagian proses yang lebih detail serta menggambarkan arus datanya. DFD Level- 0 seperti pada gambar 1.4 sebagai berikut :

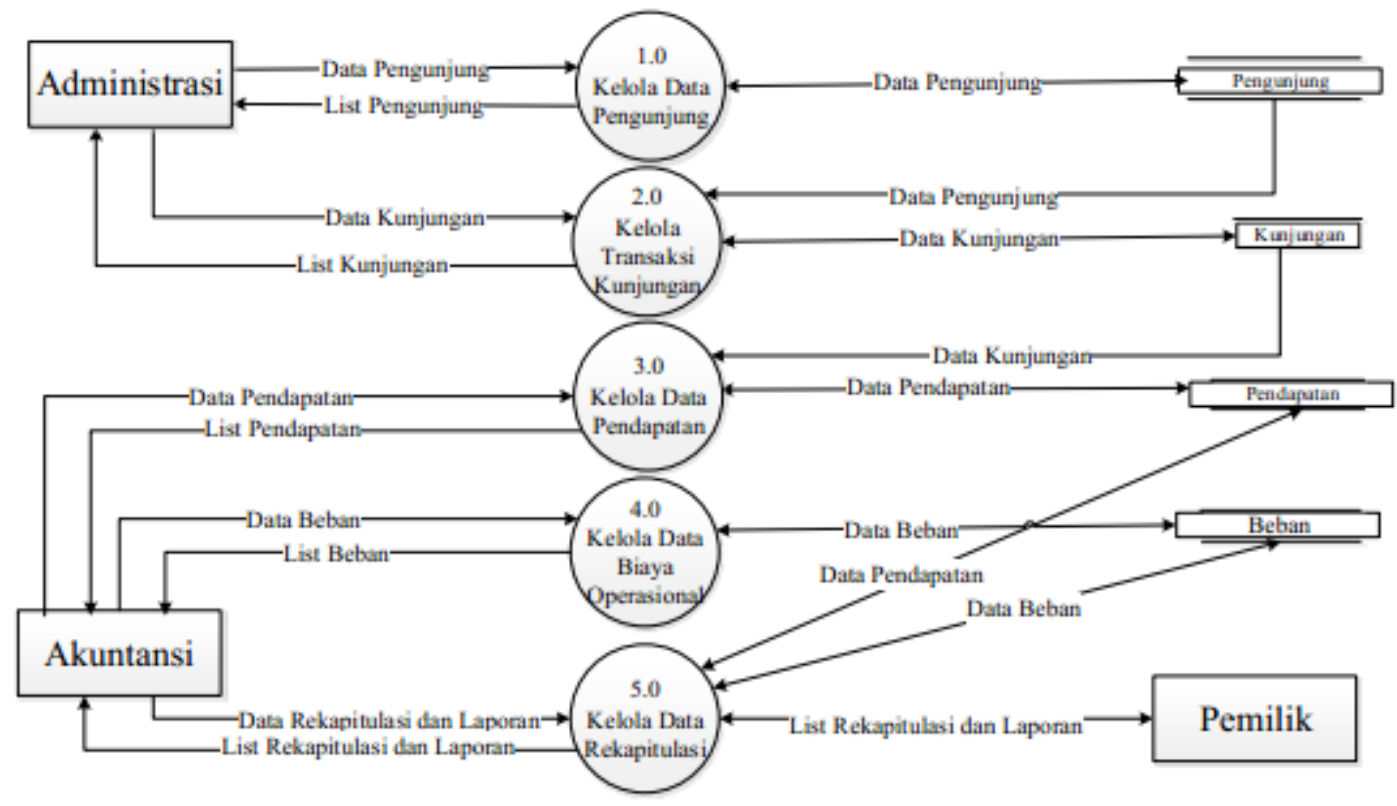

Gambar 1.4 DFD Level- 0 Aplikasi Sistem Perhitungan Laporan Laba Rugi Menggunakan Metode Single Step.

Gambar 1.4 diatas adalah rancangan diagram aliran data untuk Aplikasi Sistem Perhitungan Laporan Laba Rugi Menggunakan metode single step pada Champion GymCirebon.

\section{Keterangan :}


List Pengunjung terdiri dari pengunjung harian dan pengunjung anggota member.

List Kunjungan terdiri dari transaksi yang terjadi yang berasal dari pengunjung harian dan pengunjung anggotamember, penggunaan pelatih dan penggunaan fasilitas lainlain yang berupa makanan dan minuman yang ada di Champion Gym.

List Pendapatan terdiri dari segala transaksi yang berupa pendapatan penggunjung harian, pengunjung anggota member, penggunaan pelatih dan pembelian fasilitas $l$ ain lain seperti makanan dan minuman yang ada di Champion Gym.

List Beban terdiri dari biaya yang di keluarkan yaitu biaya gaji, biaya listrik, beban telepon, beban air, beban fasilitas, beban pelatih, beban penyusutan peralatan, beban pemeliharaan aktivatetap dan beban penyusutan gedung.

List Rekapitulasi dan Laporan terdiri dari seluruh rekapitulasi laporan pendapatan, laporan beban dan laporan laba rugi yang dapat dilihat dalam periode tertentu.

\section{Tampilan Input Program}

Berikut ini adalah form - form ya ng terdapat pada Aplikasi Sistem informasi Perhitungan Laporan Laba Rugi Menggunakan Metode Single Step Pada Champion Gym sebagai berikut :

\section{Form Login}

Form Login padagambar3.5. yakni form yang digunakan olehuser untuk mengakses aplikasi Sistem Perhitungan Lapora n Laba Rugi Menggunakan Metode Single Step pada Champion Gym.Terdapat 3 username yang digunakan yaitu username bagian adminstrasi, bagian akuntansi dan pemilik
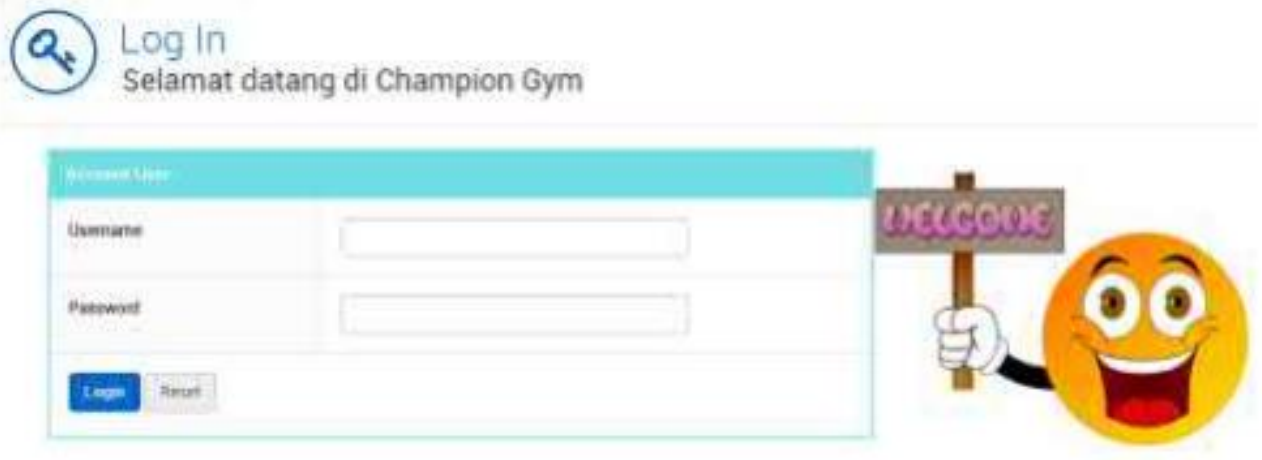

Gambar 1. 5. Form Login

\section{Form Menu Adminstrasi}

Form Menu Adminstrasi pada gambar 1.6. yakni form yang digunakan oleh user bagian administrasi untuk mengakses menu - menu aplikasi yang dapat digunakan oleh bagian administrasi sesuai dengan hak akses yang dimilikinya. Bagian Adminstrasi mengelola daftar pengunjung dan daftar kunjungan pada Champion Gym.

- Pada keterangan bagian A adminstrasi dapat langsung mengklik ke daftar pengunjung dan daftar kunjungan dan dapat melakukan logout dari tampilan menu utama adminstrasi.

- Pada keterangan bagian B adminstrasi dapat langsung juga mengklik ke daftar pengunjung dan daftar kunjungan dan dapat melakukan logout dari tampilan menu utama adminstrasi. 
Suwandi, et, al. (2019). Perancangan sistem informasi akuntansi metode single step untuk menghitung laba rugi studi kasus pada.....

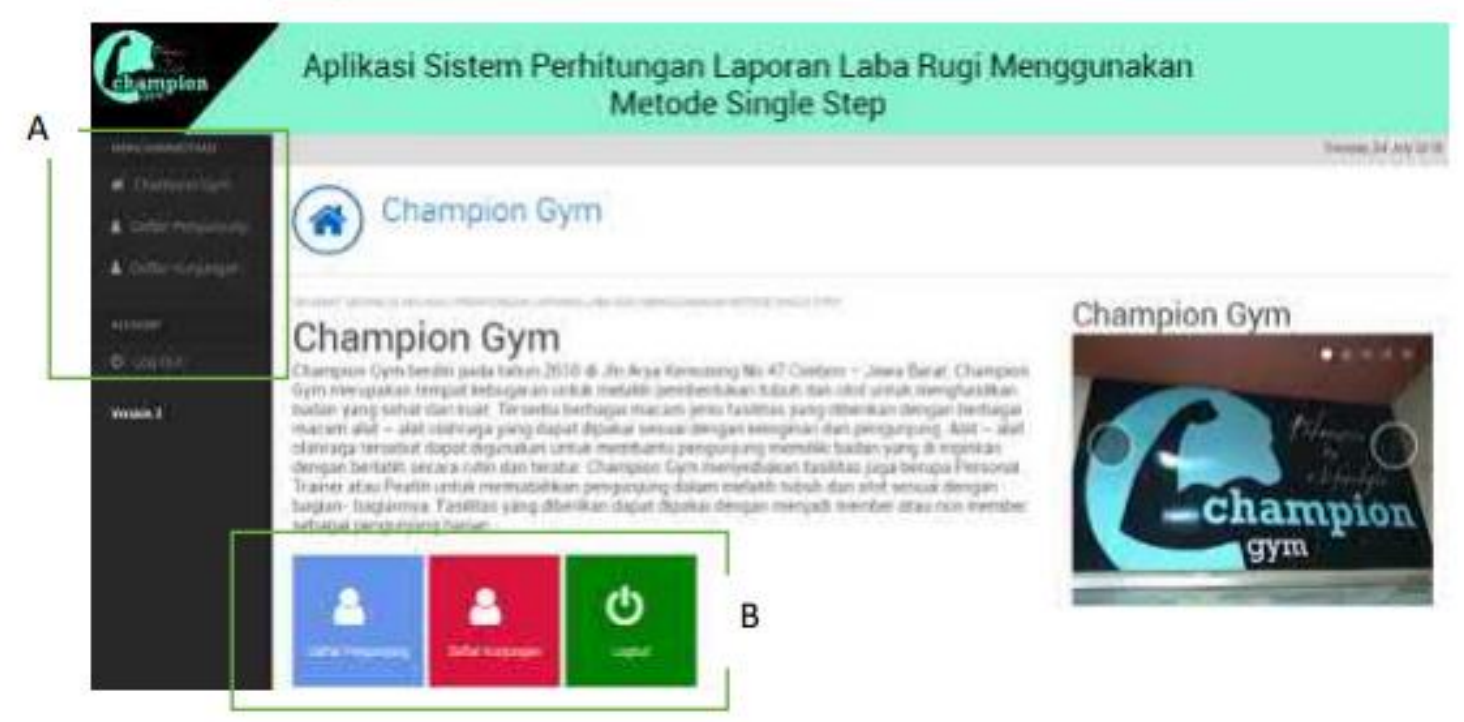

Gambar 1.6 . Form Menu Adminstrasi

\section{Form Menu Akuntansi}

Form Menu Adminstrasi p ada gambar 1.7. yakni form yang digunakan oleh user bagian akuntansi untuk mengakses menu - menu aplikasi yang dapat digunakanoleh bagian akuntansi sesuai dengan hak akses yang dimilikinya. Bagian akuntansi mengelola pendapatan,beban dan membuat laporan laba rugi dan juga mengecek cash opname.

- Pada keterangan bagian A akuntansi dapat langsung mengklik ke pendapatan,beban,laporan laba rugi dan cash opname dan dapat melakukan logout dari tampilan menu utama akuntansi.

- Pada keterangan bagian B akuntansi dapat langsung mengklik ke pendapatan,beban,laporan laba $r$ ugi dan cash opname dan dapat melakukan logout dari tampilan menu utama akuntansi

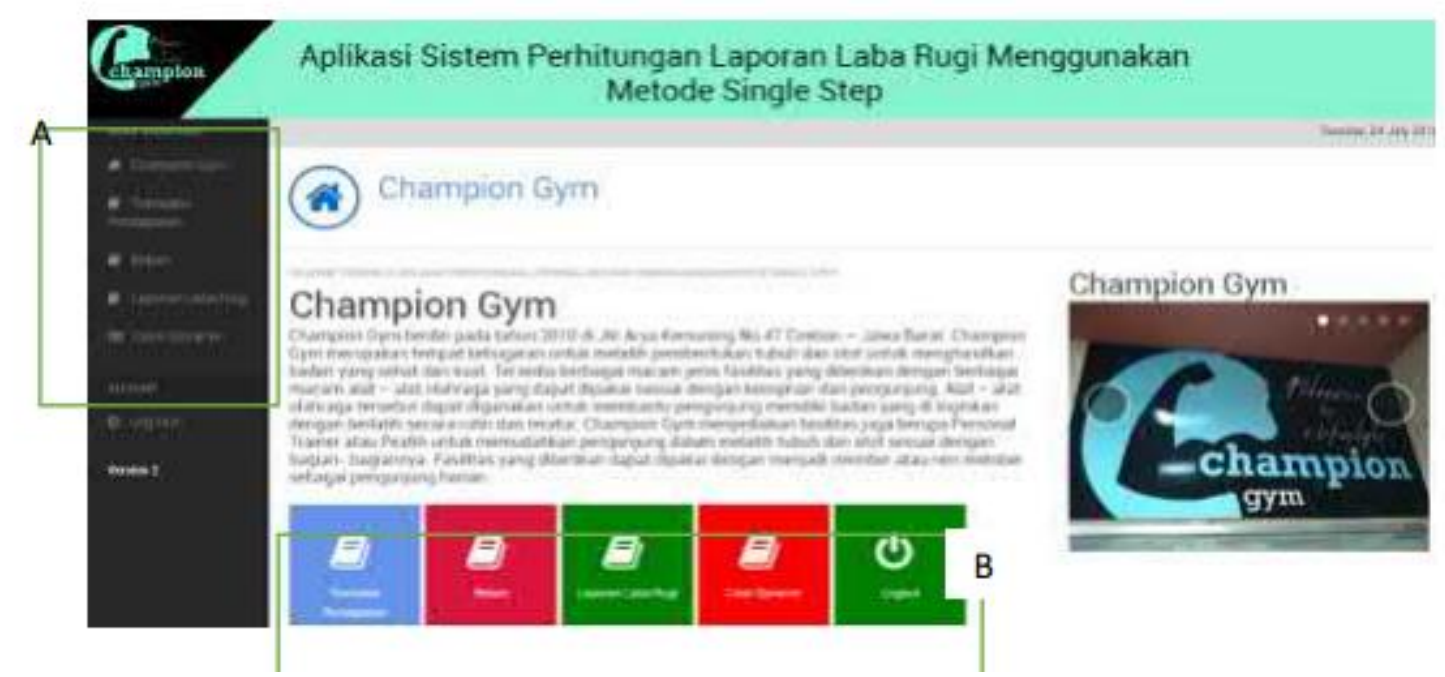

Gambar 1. 7. Form Menu Akuntansi 


\section{Form Menu Pemilik}

Form Menu Pemilik pada gambar 1. 8. yakni form yang digunakan oleh user pemilik untuk mengakses menu- menu aplikasi yang dapat digunakan oleh pemilik sesuai dengan hak akses yang dimilikinya.

Pemilik menerima laporan daftar pengunjung,laporan daftar kunjungan yang dibuat dari bagian akuntansi, kemudian menerima laporan pendapatan, laporan beban dan laporan laba rugi dari bagian adminstrasi.

- Pada keterangan bagian A pemilik dapat langsung mengklik untuk melihat laporan daftar kunjungan, laporan daftar pengunjung, laporan pendapatan, laporan beban dan laporan laba rugi.

- Pada keterangan bagian B pemilik dapat langsung mengklik untuk melihat laporan daftar kunjungan, laporan daftar pengunjung, laporan pendapatan, laporan beban dan laporan laba rugi.

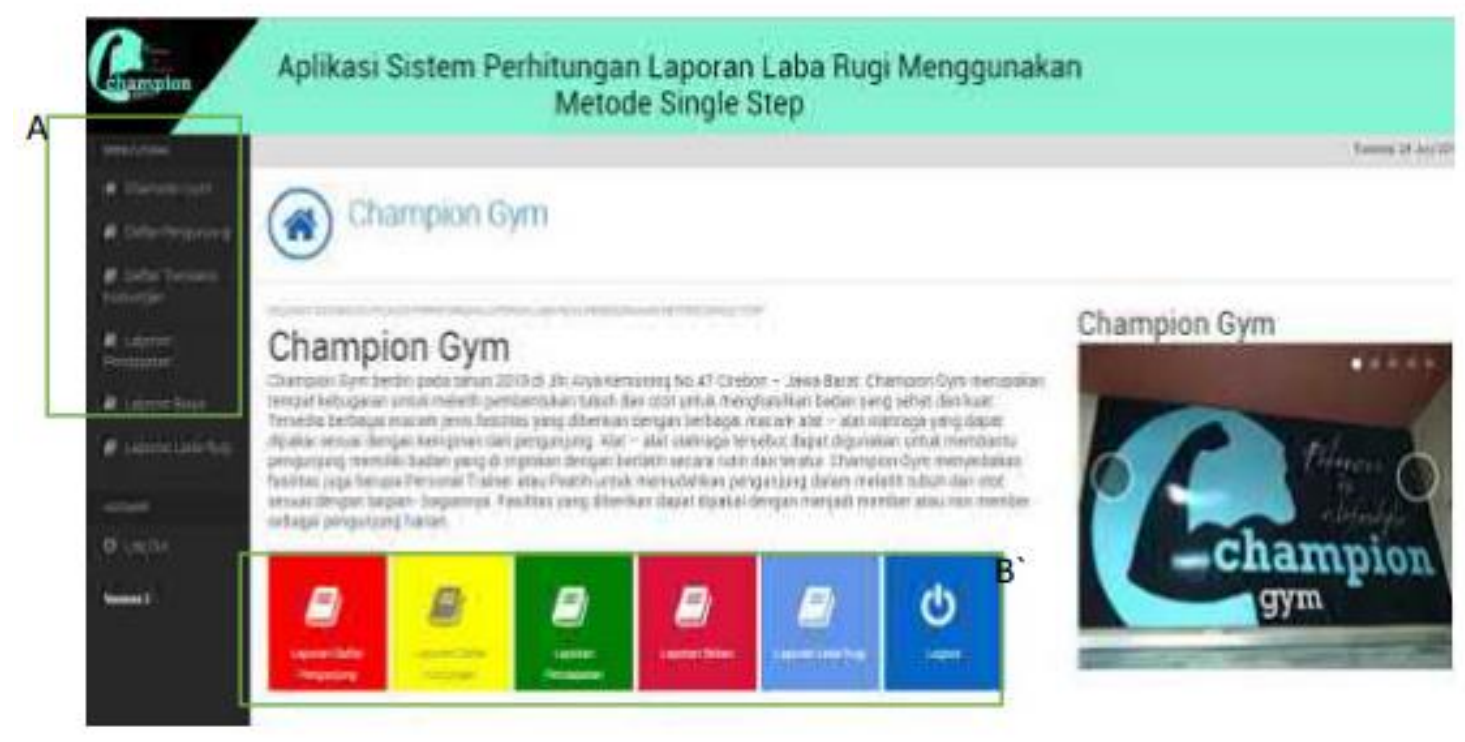

Gambar 1.8 . Form Menu Pemilik

\section{Form Tampilan Pendapatan}

Form Tampilan Pendapatan pada gambar 1.9. yakni form yang dikelola oleh akuntansi untuk menampilkan pendapatan pada Aplikasi Sistem Perhitungan Laporan Laba Rugi Menggunakan Metode Single Step pada Champion Gym.

- Pada tombol add new adalah untuk menambah pendapatan yang terdiri dari pendapatan usaha dan pendapatan lain - lain.

- Pada keterangan cetak laporan pendapatan adalah untuk mencetak laporan pendapatan yang terdiri dari pendapatan usaha dan pendapatan lain - lain.

- Pada tombol hapus adalah untuk menghapus pendapatan yang terdiri dari pendapatan usaha dan pendapatan lain - lain. 
Suwandi, et, al. (2019). Perancangan sistem informasi akuntansi metode single step untuk menghitung laba rugi studi kasus pada.....

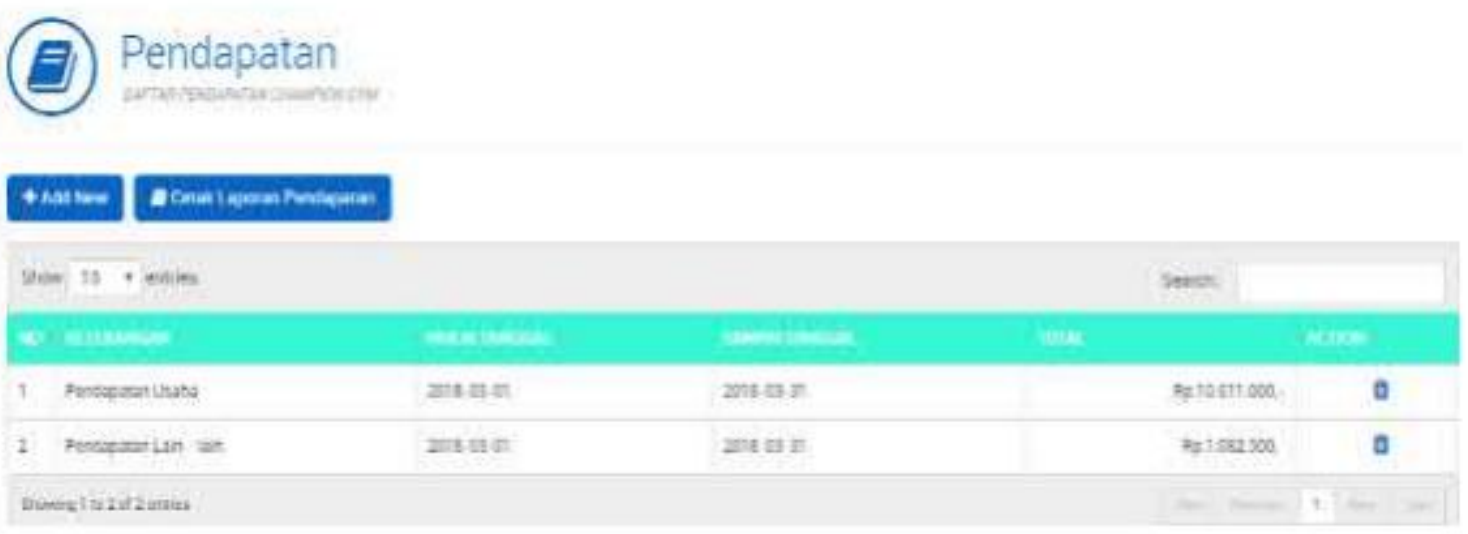

Gambar 1.9. Form Tampilan Pendapatan

\section{Form Tampilan Beban}

Form Tampilan Pendapatan pada gambar 1.10. yakni form yang dikelola oleh akuntansi untuk menampilkan beban pada Aplikasi Sistem Perhitungan Laporan Laba Rugi Menggunakan Metode SingleStep pada Champion Gym.

- Pada tombol add new adalah untuk menambah beban yang terdiri dari beban gaji, beban listrik, beban air, beban telepon, beban fasilitas, beban penyusutan peralatan, beban pemeliharaan aktiva tetap, beban penyusutan gedung.

- Pada tombol edit adalah untuk mengedit beban yang terdiri dari beban gaji, beban listrik, beban air, beban telepon, beban fasilitas, beban penyusutan peralatan, beban pemeliharaan aktiva tetap, beban penyusutan gedung.

- Pada keterangan cetak laporan beban adalah untuk mencetak laporan pendapatan yang terdiri dari beban gaji, beban listrik, beban air, beban telepon, beban fasilitas, beban penyusutan peralatan, beban pemeliharaan aktiva tetap, beban penyusutan gedung. - Pada tombol hapus adalah untuk menghapus beban yang terdiri dari beban gaji, beban listrik, beban air, beban telepon, beban fasilitas, beban penyusutan peralatan, beban pemeliharaan aktiva tetap, beban penyusutan gedung.

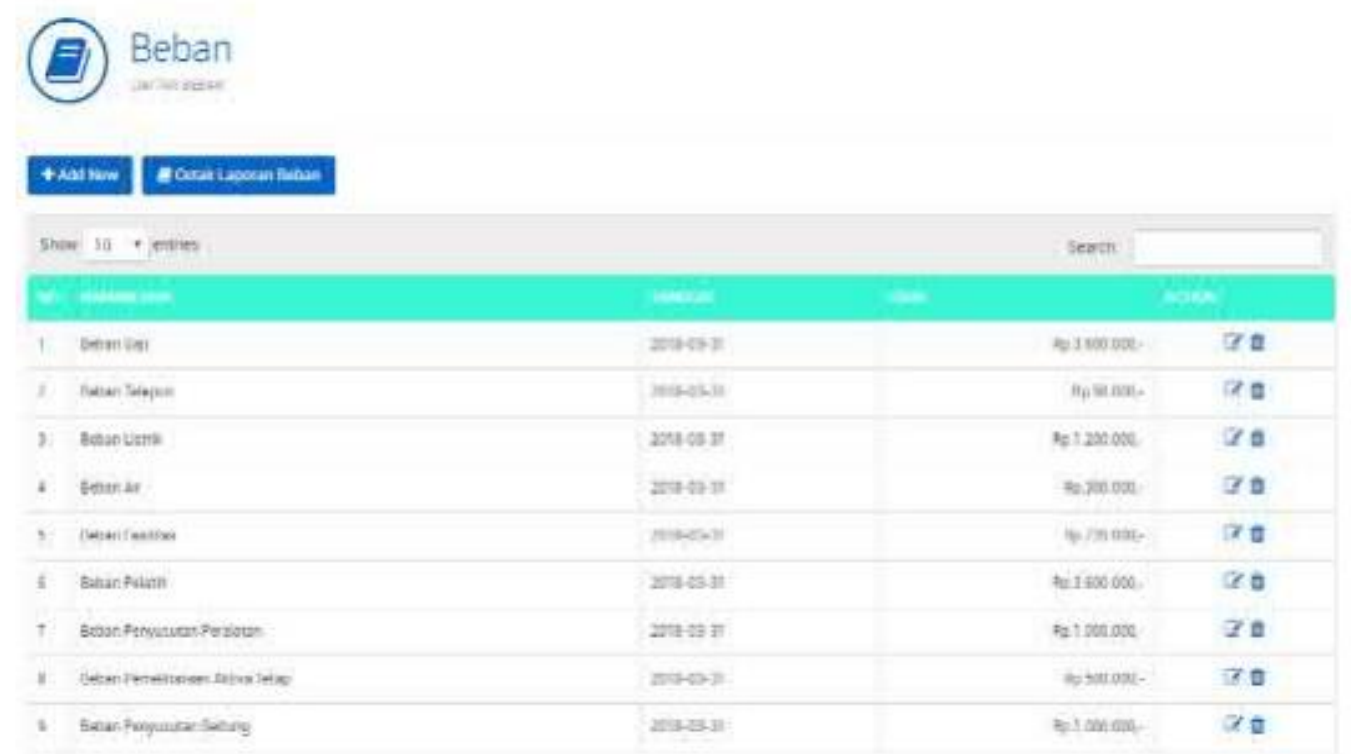

Gambar 1. 10. Form Tampilan Beban 


\section{Laporan Laba Rugi}

Laporan Laba Rugi pada gambar 1.11. yakni laporan yang dibuat oleh akuntansi dengan total laba bersih sebelum pajak di bulan berjalan sebesar Rp. 643.500 dengan metode perhitungan single step seluruh pendapatan dikurangi dengan seluruh beban .

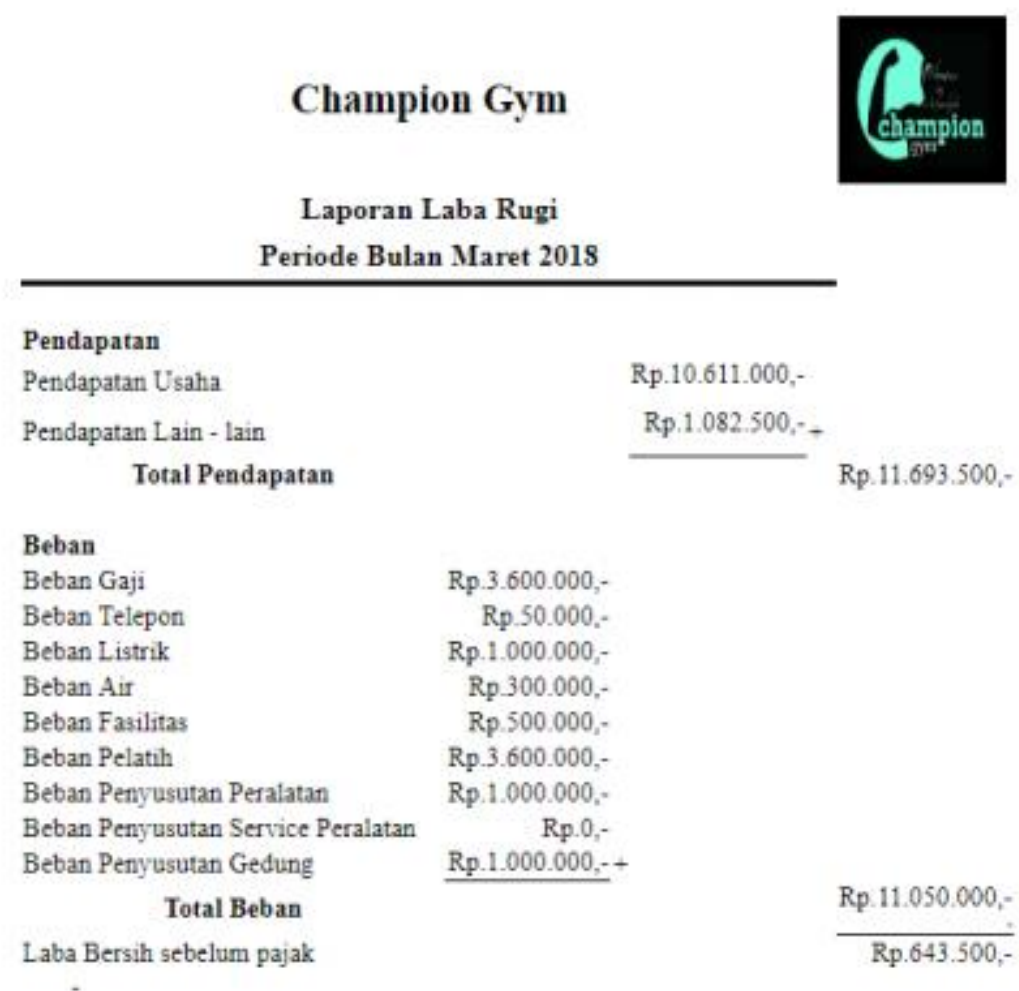

Gambar 1.11 . Laporan Laba Rugi

\section{SIMPULAN}

Setelah melalui tahapan analisis sampai dengan pembuatan Aplikasi Perhitungan Laporan Laba Rugi Menggunakan Metode Single Step Pada Champion Gym, maka dapat disimpulkan bahwa dengan dibuatnya Aplikasi Perhitungan Laporan Laba Rugi menggunakan metode Single Step pada Champion Gym, maka manajemen Champion Gym dapat menghitung secara langsung pendapatan yang diperoleh, kemudian dikurangi pengeluaran yang terjadi setiap bulannya sehingga dapat memudahkan manajemen dalam hal pengambilan keputusan.

\section{DAFTAR PUSTAKA}

Ahmad,Rizky.(2017).Sistem Informasi Akuntansi (Berbasis Akuntansi).CV Budi Utama, Yogyakarta.

Fitri, R. S., Rukun, K., \& Dwiyani, N. (2018). Perancangan dan Implementasi Sistem Informasi Penjualan Komputer dan Accessories Pada Toko Mujahidah Computer Berbasis Web. Jurnal Vokasional Teknik Elektronika dan Informatika, 4(1).

Krismiaji.(2015) . Sistem Informasi Akuntansi. Sekolah Tinggi Ilmu Manajemen YKPN, Yogyakarta. Mulyadi.(2016). Sistem Akuntansi. Salemba Empat, Jakarta.

Purnomo, J. (2015). Perancangan Aplikasi Pelaporan Keuangan Dana Bantuan Langsung Masyarakat Pengembangan Usaha Agribisnis Pedesaan (BLM-PUAP) Berbasis Web Studi Kasus Lembaga 
Suwandi, et, al. (2019). Perancangan sistem informasi akuntansi metode single step untuk menghitung laba rugi studi kasus pada.....

Keuangan Mikro Agribisnis (LKM-A) Gabungan Kelompok Tani (GAPOKTAN) Rejo Makmur Desa Sitirejo(Doctoral dissertation, Universitas Muria Kudus).

Romney, M. B., et al. (1997). Accounting Information Systems, Addison-Wesley.

Sasongko,Catur.2016. Akuntansi Suatu Pengantar -Berbasis PSAK, Salemba Empat, Jakarta

Setianingsih, H. D. (2018). Aplikasi Sistem Informasi Akuntansi Laporan Laba Rugi Pada Putri Beauty Salon Dan SPA Bandar Lampung. Jurnal JUSINTA, 1(1), 21-31.

Setiawan, B., Satoto, K. I., \& Fatchurrochim, A. (2011). Sistem Informasi Akuntansi Untuk UKM (Doctoral dissertation, Jurusan Teknik Elektro Fakultas Teknik). 